\title{
Determination of clonixin in plasma and urine by reversed-phase high-performance liquid chromatography
}

\author{
António Bica ${ }^{\mathrm{a}}$, Ascensão Farinha ${ }^{\mathrm{a}, *}$, Henning Blume ${ }^{\mathrm{b}}$, Carlos Maurício Barbosa ${ }^{\mathrm{c}, \mathrm{d}}$ \\ ${ }^{a}$ Laboratório de Estudos Farmacêuticos, Rua Alto do Duque 67, 1400 Lisbon, Portugal \\ ${ }^{\mathrm{b}}$ Johann Wolfgang Goethe-Universität, Frankfurt am Main, Germany \\ ${ }^{\mathrm{C}}$ CTMUP, Faculdade de Farmácia da Universidade do Porto, Porto, Portugal \\ ${ }^{\mathrm{d}}$ CETMED, Centro Tecnológico do Medicamento, Porto, Portugal
}

\begin{abstract}
A reversed-phase high-performance liquid chromatographic method that enables the determination of clonixin in human plasma and urine samples is described. Recovery of the drug was over 87.6 and $80.7 \%$ for plasma and urine, respectively. The limit of quantitation of the method was established as $10 \mathrm{ng} / \mathrm{ml}$ in plasma and $20 \mathrm{ng} / \mathrm{ml}$ in urine samples, with RSDs of less than $11.1 \%$. The applicability of the method was further assessed by determining the plasma concentrations time course of clonixin in six healthy volunteers after single oral dose administration of 150 and $300 \mathrm{mg}$ of clonixin and Clonix.

(C) 2000 Elsevier Science B.V. All rights reserved.
\end{abstract}

Keywords: Validation; Clonixin; Nonsteroidal anti-inflammatory drugs

\section{Introduction}

Clonixin, 2-(3-chloro-o-toluidino) nicotinic acid is a nonsteroidal anti-inflammatory drug (Fig. 1) displaying anti-inflammatory, analgesic and antipyretic

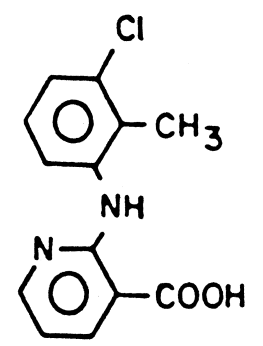

Fig. 1. Clonixin chemical structure.

*Corresponding author.

E-mail address: rcfarinha@mail.telepac.pt (A. Farinha). activity in laboratory animals [1]. Analgesic properties have been shown in monkeys [2] and in humans [3-10]. Clonixin showed a good safety profile, with analgesic efficacy, following oral administration of a $600-\mathrm{mg}$ dose, comparable to morphine sulphate $10 \mathrm{mg}$ parenterally [9]. The drug's solubility in aqueous media is very low, with a high trend for partitioning into organic solvents, as revealed by its high octanol/water partition coefficients (unpublished data).

Few methods for the assay of clonixin in biological samples have been reported. Katchen and co-workers $[11,12]$ developed a thin-layer chromatographic method following UV spectrophotometry to study the metabolism and pharmacokinetics of clonixin in rats, dogs and monkeys and in humans, following i.v. and oral administration of $2 \times 250 \mathrm{mg}$ gelatine capsules. Clonixin was found to be rapidly absorbed and excreted by humans. The excretion 
patterns of the parent compound and the urine metabolites were very similar between rhesus monkeys and humans.

González-Martin et al. [13], reported a study of the pharmacokinetics of the lysine salt of clonixin in 10 children in postoperative care, aged $4-10$ years old. Serum clonixin concentrations were determined by a revered-phase high-pressure liquid chromatographic method with a limit of quantitation (LOQ) of $100 \mathrm{ng} / \mathrm{ml}$, although further details were not provided. The pharmacokinetic parameters determined were different from those previously reported in adult humans and experimental animals.

We report here a new specific and sensitive method for the determination of clonixin in human plasma and urine samples. The method was applied to a pilot bioavailability study of clonixin in six healthy volunteers.

\section{Experimental}

\subsection{Materials}

Clonixin was a generous gift of Janssen-Cilag (Amadora, Portugal). $p$-Chlorowarfarin (internal standard, I.S.) was supplied by Aldrich (Madrid, Spain). All solvents were HPLC grade from E. Merck (Darmstadt, Germany). Other reagents were of analytical-reagent grade, also from E. Merck.

\subsection{High-performance liquid chromatography (HPLC)}

The HPLC pumping system used in this study was a Merck-Hitachi L-6000A pump. The mobile phase was $28 \%$ acetonitrile, $36 \%$ methanol and $36 \%$ of $0.3 \%$ acetic acid solution at a flow-rate of $1.0 \mathrm{ml} /$ min. Sample injection was performed with a Waters 717 Plus autosampler. The HPLC column $(250 \times 4.0$ mm I.D.) was a Nucleosil-100, 5- $\mu \mathrm{m} \mathrm{C}_{18}$ column, coupled to a $\mu$ Bondapak $\mathrm{C}_{18}$ guard-column. A Waters 486 UV detector set at $290 \mathrm{~nm}$ (0.005 AUFS) was used to monitor the column effluent. A MerckHitachi D-2500 Chromato-Integrator was used to acquire and integrate the chromatographic data.

\subsection{Plasma sample preparation}

A 1-ml plasma sample, thawed at room temperature, was spiked with $50 \mu \mathrm{l}$ of a $21.4-\mu \mathrm{g} / \mathrm{ml}$ I.S and mixed with $50 \mu \mathrm{l}$ of $6 M$ hydrochloric acid in a glass screw-capped tube. To each sample, $4 \mathrm{ml}$ of a mixture of chloroform-methanol (99.5:0.5) were added and the tubes thoroughly mixed for $15 \mathrm{~min}$. After centrifugation at $4500 \mathrm{rpm}$ for $5 \mathrm{~min}$, the organic layer was transferred to a clean glass tube. The remaining aqueous layer was again extracted with additional $4 \mathrm{ml}$ of the chloroform-methanol solution. The organic layer was transferred to the tube containing the first $4 \mathrm{ml}$ organic phase from the previous extraction step. The pooled organic layers were evaporated to dryness at $45^{\circ} \mathrm{C}$ under a stream of nitrogen. The dry residue was reconstituted with 100 $\mu l$ of methanol. Twenty- $\mu$ l samples were injected into the HPLC apparatus.

\subsection{Urine sample preparation}

Frozen urine was allowed to thaw at room temperature. The internal standard ( $p$-chlorowarfarin solution at $21.4 \mu \mathrm{g} / \mathrm{ml}), 50 \mu \mathrm{l}$ of $6 M$ hydrochloric acid, $50 \mathrm{mg}$ of sodium chloride and $4 \mathrm{ml}$ of a mixture of chloroform-methanol (99.5:0.5) were added to a $1.0-\mathrm{ml}$ urine aliquot in a screw-capped glass tube. The tubes were thoroughly mixed for 15 min. After centrifugation at $4500 \mathrm{rpm}$ for $5 \mathrm{~min}$, the organic layer was transferred to a clean glass tube and evaporated to dryness under a stream of nitrogen at $45^{\circ} \mathrm{C}$. The residue was reconstituted with $100 \mu \mathrm{l}$ of methanol and $20 \mu \mathrm{l}$ were injected into the HPLC apparatus.

\subsection{Validation study}

To assess linearity in plasma samples, two calibration curves were prepared. A lower calibration curve ranging from 0.010 to $2.0 \mu \mathrm{g} / \mathrm{ml}$ and a upper calibration curve ranging from 0.10 to $26.6 \mu \mathrm{g} / \mathrm{ml}$. A single calibration range was prepared in urine from 0.020 to $2.0 \mu \mathrm{g} / \mathrm{ml}$. Standard samples were prepared by spiking drug-free plasma and urine with clonixin and the internal standard following extraction and analysis as described above. The peak height ratios of clonixin to the internal standard were 
measured and the calibration curves were obtained by least-squares weighted $\left(1 / \mathrm{conc}^{2}\right)$ linear regression. Regression lines were used to determine clonixin concentrations in the test samples.

The absolute recovery of clonixin extracted from urine and plasma samples was assessed by comparing the peak heights of extracted plasma and urine samples, containing known amounts of drug, with those obtained from standard solutions of clonixin, prepared in methanol-water (1:1), at the same concentration levels. The concentrations of clonixin tested in plasma samples were $0.010,0.020,0.40$ and $2.0 \mu \mathrm{g} / \mathrm{ml}$, while in urine samples the concentration levels were $0.020,0.40$ and $2.0 \mu \mathrm{g} / \mathrm{ml}$.

Intra- and inter-assay RSDs and relative errors (REs) were used to assess the precision and accuracy of the methods. In plasma samples these concentration levels were $0.010,0.020,0.40,2.0$ and 8.5 $\mu \mathrm{g} / \mathrm{ml}$. Additional evaluation for precision and accuracy was performed at 15.9 and $26.6 \mu \mathrm{g} / \mathrm{ml}$. In urine samples the tested levels were those used for assessing absolute recovery.

Validation studies also included specificity tests in six individual plasma and urine samples, room temperature stability, long-term stability and freezethaw stability.

\subsection{Application of the plasma method}

The analytical procedure was applied to the analysis of plasma samples from a pilot pharmacokinetic and bioavailability study of clonixin, following the administration of Clonix (Janssen-Cilag) 300-mg immediate release gelatine capsules, from a commercially available batch (no. 7G128A; expiry date, July 2000) and two, 150 and $300 \mathrm{mg}$, in house-prepared oral aqueous solutions. Six healthy male volunteers, aged 22-31 years, participated in the clinical investigations. None of the subjects had any relevant medical history or was on any other medication. Subjects fasted overnight prior to the administration at 08:00 h. Blood samples were withdrawn until $14 \mathrm{~h}$ post-administration and transferred to lithium heparin Luer Monovette tubes (Sarstedt, Portugal). The resulting plasma $\left(2500 \mathrm{rpm}\right.$ for $\left.10 \mathrm{~min}, 5^{\circ} \mathrm{C}\right)$ was stored frozen below $-20^{\circ} \mathrm{C}$ in polypropylene tubes, pending analysis. All the subjects gave informed written consent prior to the start of the study, which had the approval of the clinical unit Ethics Committee.

\subsection{Pharmacokinetic analysis}

All pharmacokinetic parameters were determined by non-compartmental models. The slope of the terminal $\log$-linear portion of the clonixin concentration versus time profiles was determined by the best fit least-squares regression analysis and used as the elimination rate constant $\left(K_{\mathrm{e}}\right)$. The apparent elimination half-life $\left(t_{1 / 2}\right)$ was determined as $\ln 2 /$ $K_{\mathrm{e}}$. The area under the concentration versus time curve of clonixin in plasma from time zero to the last quantifiable point $\left(\mathrm{AUC}_{0-t}\right)$ was calculated by the linear trapezoidal rule, from time zero to $t_{\max }$, and by the log-linear trapezoidal rule, beyond $t_{\max }$ until the last quantifiable point $\left(C_{t}\right)$. Extrapolated area under the curve, from $C_{t}$ to infinity $\left(\mathrm{AUC}_{t-\mathrm{inf}}\right)$ was determined as $C_{t} / K_{\mathrm{e}}$. Total area under the curve $\left(\mathrm{AUC}_{0-\text { inf }}\right)$ was the sum of $\mathrm{AUC}_{0-t}$ and $\mathrm{AUC}_{t-\mathrm{inf}}$. The maximum plasma concentration $\left(C_{\max }\right)$ and the time to reach $C_{\max }\left(t_{\max }\right)$ were taken directly from the observed concentration versus time data.

\section{Results and discussion}

The chromatograms of blank plasma, spiked plasma with clonixin and internal standard and plasma from a subject dosed with Clonix, are shown in Fig. $2 \mathrm{a}-\mathrm{c}$, respectively. Chromatograms of blank urine and urine spiked with clonixin and internal standard are shown in Fig. 3a,b. No interfering peaks were observed at the clonixin retention times.

The absolute recovery of clonixin from plasma and urine samples (Table 1) ranged from 87.6 to $96.4 \%$ and 80.7 to $90.1 \%$, respectively. All calibration lines showed to be linear over the concentrations range examined with a $r>0.9953$.

Tables 2 and 3 include the data obtained for the precision and accuracy. Maximum intra- and interday precision was 11.06 and $8.07 \%$ for plasma and urine, respectively. The accuracy observed for plasma and urine samples, ranged from -1.67 to $10.70 \%$ and from -1.90 to $7.68 \%$, respectively. Additional data obtained during the analysis of plasma samples from the pilot study, showed RSDs 


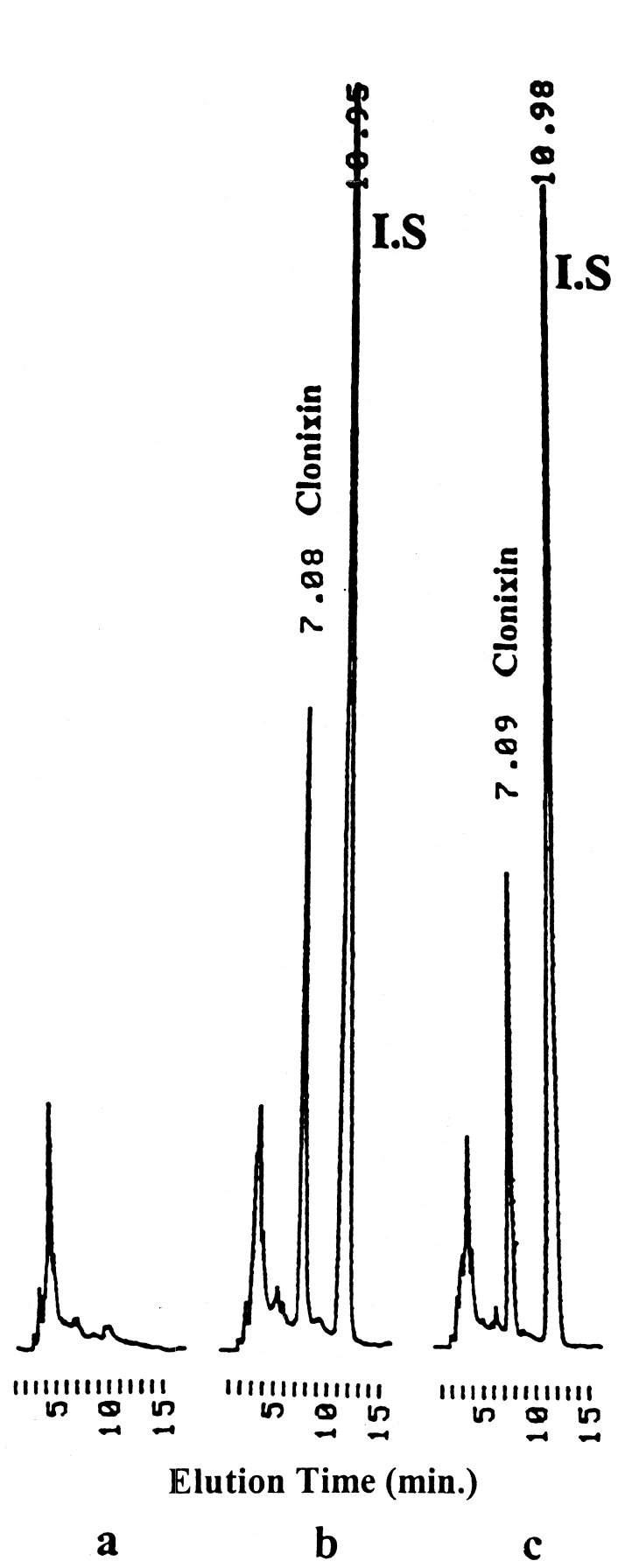

Fig. 2. Typical chromatograms of a blank plasma sample (a), a plasma spiked with clonixin and I.S. (b) and a sample from a subject dosed with Clonix (c).

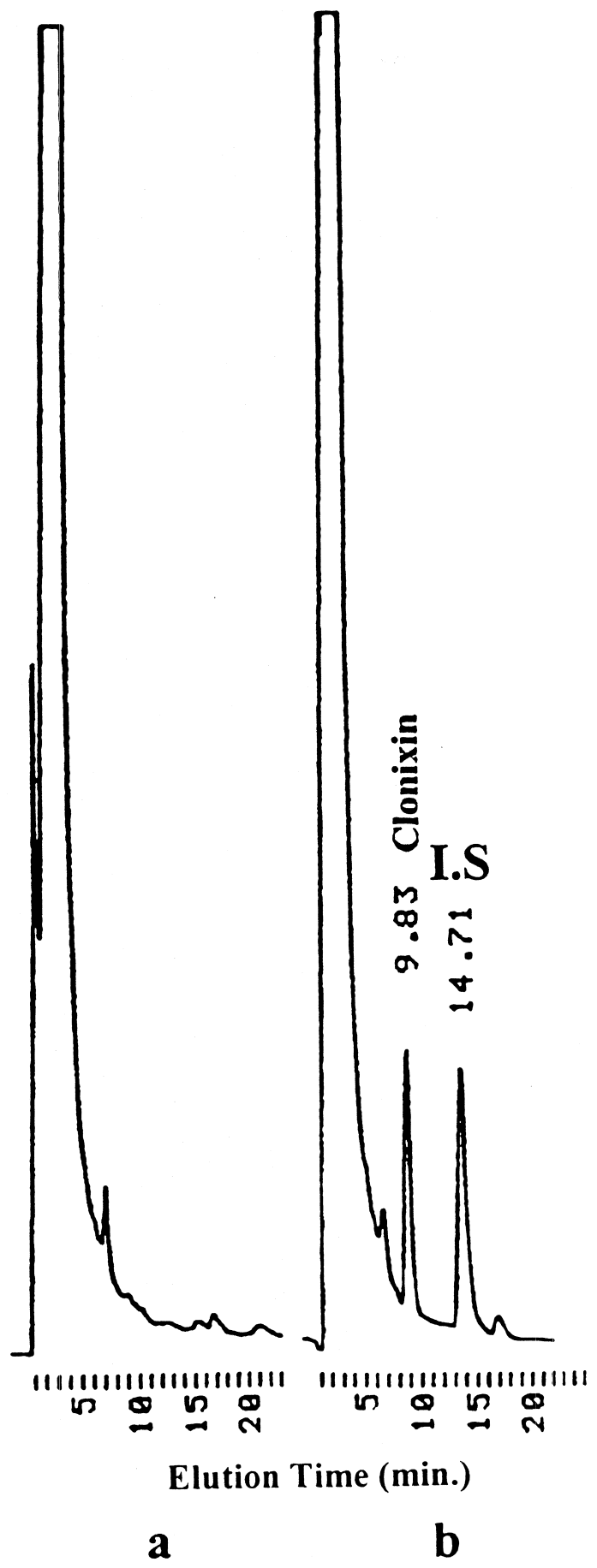

Fig. 3. Typical chromatograms of a blank urine sample (a) and a urine sample spiked with clonixin and I.S. (b). 
Table 1

Recovery of clonixin from plasma and urine

\begin{tabular}{lllc}
\hline & $\begin{array}{l}\text { Concentration } \\
\text { added }(\mu \mathrm{g} / \mathrm{ml})\end{array}$ & Recovery $(\%)$ & RSD $(\%)$ \\
\hline Plasma & 1.996 & 87.6 & 14.6 \\
$(n=6)$ & 0.399 & 88.5 & 6.3 \\
& 0.020 & 96.4 & 7.1 \\
& 0.010 & 91.3 & 5.5 \\
Urine & 2.005 & 88.0 & 5.3 \\
$(n=6)$ & 0.400 & 90.1 & 4.3 \\
& 0.020 & 80.7 & 12.9 \\
\hline
\end{tabular}

of $3.22 \%(n=6)$ and $6.79 \%(n=8)$, at 16.0 and 26.6 $\mu \mathrm{g} / \mathrm{ml}$, respectively, while accuracy was $1.29 \%$ and $-0.06 \%$, respectively. The LOQ was defined as the minimum determinable concentration with a relative error below 20\% [14]. This was $10 \mathrm{ng} / \mathrm{ml}$ (RE, $-1.67 \%$ ) and $20 \mathrm{ng} / \mathrm{ml}$ (RE, $-1.90 \%$ ), respectively, in plasma and urine. This limit of quantification is 10 times lower than that reported by Gonzáles-Martin et al. [13], for serum samples.

Clonixin proved to be stable under different conditions. After three freeze-thaw stability cycles of samples spiked with $0.4 \mu \mathrm{g} / \mathrm{ml}$ of clonixin $(n=$ 6), a negligible difference was observed from time zero to the last cycle. At room temperature, clonixin showed to be stable for at least $24 \mathrm{~h}$, both in plasma and urine samples at $0.4 \mu \mathrm{g} / \mathrm{ml}(n=6)$, with -3.3 and $-4.6 \%$ differences observed from time zero to $24 \mathrm{~h}$ after sample preparation.

Long-term stability of stored samples at or below $-20^{\circ} \mathrm{C}$ was assessed by analysing six replicate stability samples at a nominal concentration of 0.4 $\mu \mathrm{g} / \mathrm{ml}$ in comparison with daily prepared samples at the same concentration level. Plasma samples proved to be stable for at least 14 weeks $(-3.4 \%)$, while urine samples were stable for at least 4 weeks $(+3.5 \%)$. These results indicate a good stability of clonixin in both types of biological matrix. So far, no

Table 2

Within and between-day precision and accuracy for plasma samples

\begin{tabular}{lllrr}
\hline & $\begin{array}{l}\text { Concentration } \\
\text { added }(\mu \mathrm{g} / \mathrm{ml})\end{array}$ & $\begin{array}{l}\text { Concentration found } \\
(\mu \mathrm{g} / \mathrm{ml})\end{array}$ & RSD $(\%)$ & RE $(\%)$ \\
\hline Within-day & 8.506 & $9.416 \pm 0.6343$ & 6.74 & 10.70 \\
$(n=6)$ & 1.996 & $2.071 \pm 0.0390$ & 1.88 & 3.74 \\
& 0.399 & $0.425 \pm 0.0138$ & 3.26 & -1.25 \\
& 0.020 & $0.0198 \pm 0.0010$ & 5.18 & -1.67 \\
Between-day & 0.010 & $0.0098 \pm 0.0011$ & 6.06 & 1.33 \\
$(n=12)$ & 8.506 & $8.619 \pm 0.5351$ & 6.21 & 4.52 \\
& 1.996 & $2.086 \pm 0.1441$ & 6.91 & -1.11 \\
& 0.399 & $0.403 \pm 0.0379$ & 9.40 & -1.53 \\
\hline
\end{tabular}

Table 3

Within and between-day precision and accuracy for urine samples

\begin{tabular}{llllr}
\hline & $\begin{array}{l}\text { Concentration } \\
\text { added }(\mu \mathrm{g} / \mathrm{ml})\end{array}$ & $\begin{array}{l}\text { Concentration found } \\
(\mu \mathrm{g} / \mathrm{ml})\end{array}$ & RSD $(\%)$ & RE $(\%)$ \\
\hline Within-day & 2.005 & $2.021 \pm 0.0218$ & 1.08 & 0.77 \\
$(n=6)$ & 0.400 & $0.414 \pm 0.0203$ & 4.89 & 3.48 \\
& 0.020 & $0.0196 \pm 0.0015$ & 7.72 & 5.90 \\
Between-day & 2.005 & $2.118 \pm 0.0933$ & 4.40 & 5.64 \\
$(n=18)$ & 0.400 & $0.431 \pm 0.0237$ & 5.50 & 7.68 \\
& 0.020 & $0.0202 \pm 0.0016$ & 8.07 & 1.15 \\
\hline
\end{tabular}




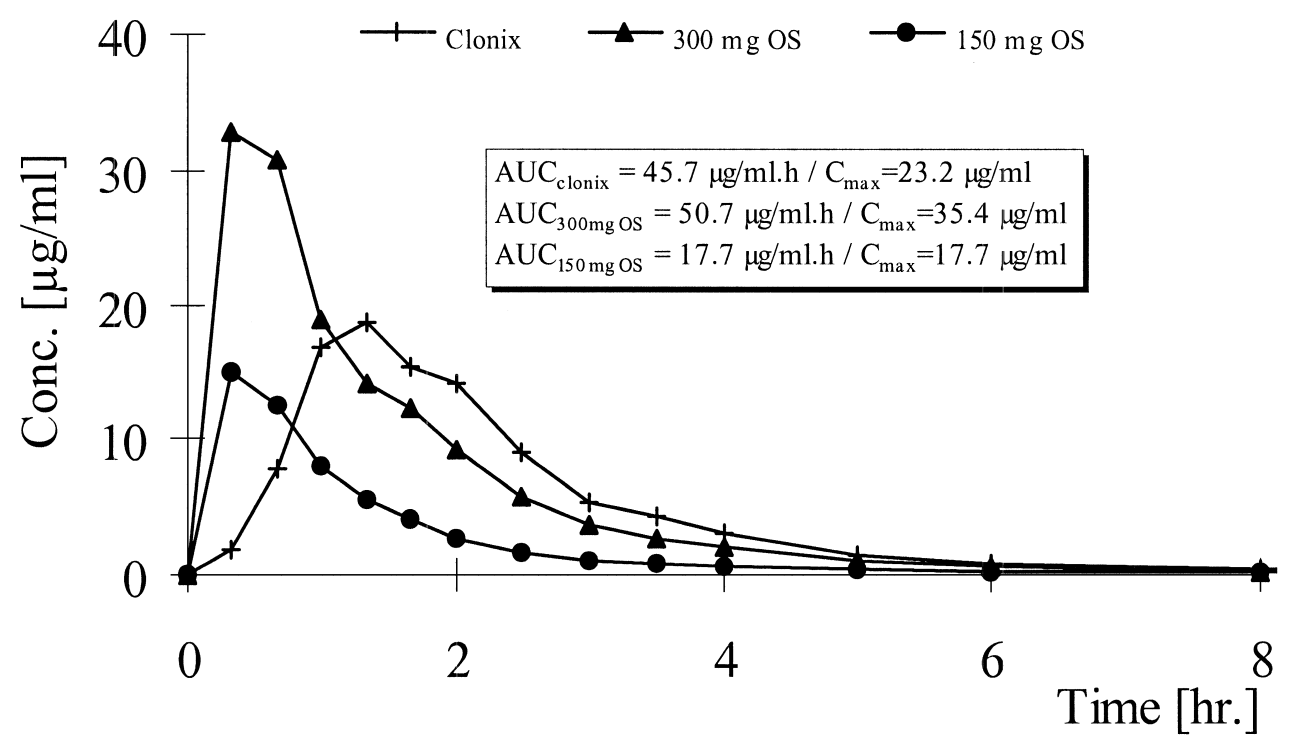

Fig. 4. Mean plasma levels of clonixin with AUC and $C_{\max }$ results $(n=6)$.

information regarding clonixin stability in biological samples has been published.

Fig. 4 shows the mean plasma profiles of clonixin $(n=6)$ following administration of the three study formulations. Geometric mean $\mathrm{AUC}_{0-\text { inf }}$ values $(n=$ 6) represent essentially true experimental values, as the mean extrapolated $\mathrm{AUC}_{t-\mathrm{inf}}$, was $0.01 \%$ for both Clonix and the $300 \mathrm{mg}$ oral solution and $0.03 \%$ for the $150 \mathrm{mg}$ oral solution. As indicated by the $C_{\max }$ values, clonixin absorption was considerably retarded after administration of the solid oral formulation, when compared with the oral solutions. However, the rate of absorption remained unchanged when the same formulation was given at two different dose levels.

The plasma elimination rate constant $\left(0.45 \mathrm{~h}^{-1}\right)$ was very similar for all three formulations and in accordance with that previously reported [11], following single oral dose administration of a solid preparation. The apparent elimination half-lives were 1.6, 1.7 and $1.5 \mathrm{~h}$, respectively, for Clonix, the $300-\mathrm{mg}$ and the $150-\mathrm{mg}$ oral solutions.

Analysis of variance $\left(\mathrm{ANOVA}_{\log }\right)$ intra-subject RSDs for the comparison of Clonix versus. the 300 mg solution, were 14.1 and $24.8 \%$, respectively, for
AUC and $C_{\max }$. Similar results were obtained from the analysis of both oral solutions, with ANOVA $_{\log }$ intra-subject RSDs of 15.5 and $18.8 \%$, respectively, for $\mathrm{AUC}_{0-\text { inf }}$ and $C_{\max }$.

The results reported clearly show that the validated HPLC method for plasma samples is applicable for the determination of clonixin in human plasma samples from pharmacokinetic studies.

\section{References}

[1] A.S. Watnick, R.I. Taber, I.I. Tabachnick, Arch. Int. Pharmacodyn. 190 (1971) 78.

[2] V.B. Ciofalo, J. Patel, R.I. Taber, Jpn. J. Pharmacol. 22 (1972) 749.

[3] H. Frerick, Zahnarztliche Praxis 10 (1994) 342.

[4] M.L. Marti, C. Fraga, J.A. Pezza, Prensa Méd. Argentina S8 (1993) 695.

[5] G. Nassoweter, Presented at the 1st International Conference on Pain, Buenos Aires, 19-20 April.

[6] M. Osswald, H. Frerick, J. Maisenbacher, N. Schenk, P. Grabner, ZWR 103 (1994) 381.

[7] H. Paredes, M. Camus, G. Ballesteros, C. Rondon, Presented at the 7th World Congress on Pain, Paris, 22-27 August.

[8] K. Schaffer, C.H. Wauschkuhn, Presented at the 7th World Congress on Pain, Paris, 22-27 August. 
[9] J.S. Finch, T.J. DeKornefeld, J. Clin. Pharmacol. 15 (1971) 371.

[10] J.M.G. Santos Bessa, J.M. Silva e Costa, Rev. Portuguesa Clín. Ter. 9 (1985) 1.

[11] B. Katchen, S. Buxbaum, J. Meyer, J. Ning, J. Pharamacol. Exp. Ther. 184 (1973) 453.
[12] B. Katchen, S. Buxbaum, J. Ning, J. Pharmacol. Exp. Ther. 187 (1973) 152.

[13] G. González-Martin, C. Cattan, S. Zuñiga, Int. J. Clin. Pharmacol. Ther. 34 (1996) 396.

[14] V.P. Shah et al., J. Pharm. Sci. 81 (1992) 309. 